\title{
Leaf dimorphism of Microgramma squamulosa (Polypodiaceae): a qualitative and quantitative analysis focusing on adaptations to epiphytism
}

\author{
Ledyane Dalgallo Rocha ${ }^{1}$, Annette Droste ${ }^{1}$, Günther Gehlen ${ }^{1}$ \& Jairo Lizandro Schmitt ${ }^{1}$ \\ 1. Programa de Pós-Graduação em Qualidade Ambiental, Universidade Feevale, RS 239, 2755 - Novo Hamburgo-RS, \\ 93352-000, Brazil; ledyane@gmail.com, annette@feevale.br, guntherg@feevale.br, jairols@feevale.br
}

\author{
Received 08-XII-2011. C Corrected 04-VIII-2012. Accepted 03-IX-2012.
}

\begin{abstract}
The epiphytic fern Microgramma squamulosa occurs in the Neotropics and shows dimorphic sterile and fertile leaves. The present study aimed to describe and compare qualitatively and quantitatively macroscopic and microscopic structural characteristics of the dimorphic leaves of M. squamulosa, to point more precisely those characteristics which may contribute to epiphytic adaptations. In June 2009, six isolated host trees covered by M. squamulosa were selected close to the edge of a semi-deciduous seasonal forest fragment in the municipality of Novo Hamburgo, State of Rio Grande do Sul, Brazil. Macroscopic and microscopic analyzes were performed from 192 samples for each leaf type, and permanent and semi-permanent slides were prepared. Sections were observed under light microscopy using image capture software to produce illustrations and scales, as well as to perform quantitative analyses. Fertile and sterile leaves had no qualitative structural differences, being hypostomatous and presenting uniseriate epidermis, homogeneous chlorenchyma, amphicribal vascular bundle, and hypodermis. The presence of hypodermal tissue and the occurrence of stomata at the abaxial face are typical characteristics of xeromorphic leaves. Sterile leaves showed significantly larger areas $\left(14.80 \mathrm{~cm}^{2}\right)$, higher sclerophylly index $\left(0.13 \mathrm{~g} / \mathrm{cm}^{2}\right)$ and higher stomatal density $\left(27.75 \mathrm{stomata} / \mathrm{mm}^{2}\right)$ than fertile leaves. The higher sclerophylly index and the higher stomatal density observed in sterile leaves are features that make these leaves more xeromorphic, enhancing their efficiency to deal with limited water availability in the epiphytic environment, compared to fertile leaves. Rev. Biol. Trop. 61 (1): 291-299. Epub 2013 March 01.
\end{abstract}

Key words: fertile leaf, sterile leaf, fern, epiphyte, morphometry, xeromorphism.

Epiphytes are important components of the biodiversity of tropical forests, although little is known about their structural characteristics. Ferns form a group of plants that should receive special attention in the epiphytic environment, considering that about 2600 species around the world are epiphytic (Kress 1986). Because of microclimate variations in epiphytic environments, these plants develop adaptations (Benzing 1990), which are physiological and structural changes that reduce water loss (Jones 1987, Hietz \& Briones 1997), and mechanisms that help them to capture light (Graçano et al. 2001).

Studies about leaf anatomy are an important tool to identify differences between plant organs and adaptive strategies developed in many different environments. Hietz \& Briones (1997) studied the adaptations to epiphytism of Pleopeltis mexicana (Fée) Mickel \& Beitel. (Polypodiaceae), Phlebodium areolatum (Humb. \& Bonpl. ex Willd.) J. Sm. (Polypodiaceae) and Elaphoglossum glaucum T. Moore (Dryopteridaceae), and found an association between water availability and stomatal density. Ribeiro et al. (2007) analyzed the leaf anatomy of Anemia tomentosa (Savigny) Sw. var. anthriscifolia (Schrad.) Mickel and Anemia villosa Humb. \& Bonpl. ex Willd. (Anemiaceae), linking it with adaptative strategies to hydric stress on rocky outcrop. The purpose of most comparative anatomic studies of ferns is to describe terrestrial species and to contribute to their taxonomic classification, 
as in the studies conducted by Hernández et al. (2006) with species of Dryopteris Adans. (Dryopteridaceae) and by Hernández et al. (2008) with species of Cheilanthes Sw. (Pteridaceae). Tejero-Díez et al. (2010) compared anatomically the Polypodium plesiosorum sensu Moran (Polypodiaceae) group, in order to identify taxonomic characteristics. However, most studies have been focused on epiphytic angiosperms (Zanenga-Godoy \& Costa 2003, Proença \& Sajo 2007, Noguera-Savelli \& Jáuregui 2011).

Polypodiaceae shows pantropical distribution, with about 12000 species (Smith et al. 2008). Microgramma C. Presl sensu Tryon \& Tryon (1982) comprises of 30 species (Salino et al. 2008). Their leaves are glabrous or scaly, monomorphic or dimorphic (Tryon \& Tryon 1982) with a coriaceous texture, which is an adaptation to the epiphytic environment (Hirsch \& Kaplan 1974). Microgramma squamulosa Kaulf. de la Sota is an epiphytic fern occurring in Peru, Bolivia, Brazil, Argentina, Paraguay and Uruguay (Tryon \& Stolze 1993), both in human-modified environments (Gonçalves \& Waechter 2003) and in natural forests (Kersten \& Silva 2002). This species presents a long rhizome from which arise the petioles of the fertile and sterile leaves, which are dimorphic (Sehnem 1970, Jaime et al. 2007, Suffredini et al. 2008).

Hirsch \& Kaplan (1974) studied the organography and development of the shoot systems of M. squamulosa and M. vacciniifolia (Langsd. \& Fisch.) Copel. to establish their taxonomic differences. The antiulcer action of M. squamulosa has been studied by Suffredini et al. (1999). Jaime et al. (2007) described the diagnostic characteristics of $M$. squamulosa to contribute to its taxonomic identification and to the control of the quality of secondary metabolites with medicinal properties. Stem and root morphology and anatomy of M. squamulosa have been characterized in the pharmacognostic study conducted by Suffredini et al. (2008). However, these studies did not analyze the structural differences between dimorphic leaves.
Epiphytic species of Polypodiaceae developed various adaptive strategies to deal with a limited availability of water which include a wide variation of anatomical and morphological characters (Dubuisson et al. 2009). The aim of this study was i) to describe and compare qualitatively and quantitatively macroscopic and microscopic structural characteristics of the dimorphic leaves of $M$. squamulosa, and ii) to point more precisely those characteristics which contribute to adaptations in the epiphytic environment.

\section{MATERIAL AND METHODS}

Study area: Fertile and sterile leaves of M. squamulosa were collected in the municipality of Novo Hamburgo, State of Rio Grande do Sul (RS), Brazil, in an area close to the edge of a fragment $\left(29^{\circ} 46^{\prime} 51.4^{\prime \prime} \mathrm{S}-50^{\circ} 58^{\prime} 31.6^{\prime \prime} \mathrm{W}\right)$ of the semi-deciduous seasonal forest (Teixeira et al. 1986) located in an Area of Special Environmental Interest. The predominant regional climate, according to Köeppen, is classified as Cfa type, being humid-temperate, with rainfall throughout the year (Moreno 1961).

Sampling: In June 2009, six isolated host trees (phorophytes) covered by an extensive $M$. squamulosa rhizome (Fig. 1A) were selected
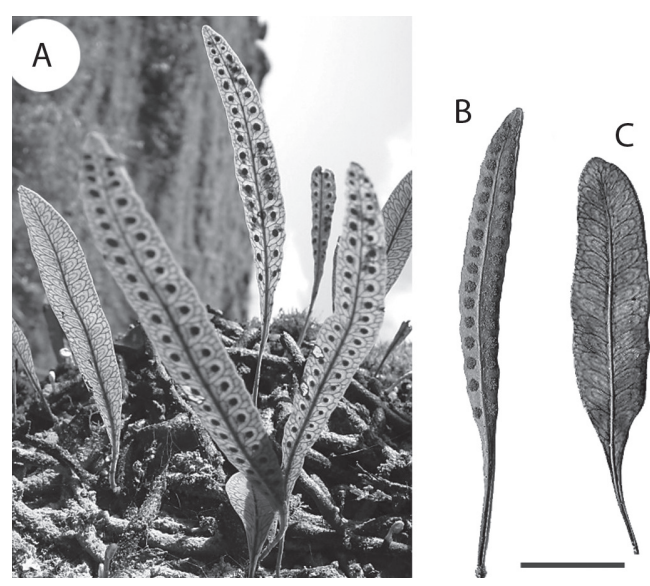

Fig. 1. (A) Microgramma squamulosa habit; (B) fertile leaf; (C) sterile leaf. Bar: $2 \mathrm{~cm}$. 
next of the edge of the forest fragment. For each leaf type (Fig. 1B, 1C), 192 samples were collected, 32 from each phorophyte. The leaves were collected from the internal area of the phorophyte canopy, where they received sunlight from the East and were exposed to a luminosity range of 22.99 to $38.73 \mu \mathrm{mol} / \mathrm{m}^{2} / \mathrm{s}$. Voucher material was deposited in the Herbarium Anchieta of the Universidade do Vale do Rio dos Sinos (PACA 108023), in São Leopoldo, RS, Brazil.

\section{Macroscopic and microscopic analyses:} For macroscopic analyses, 120 leaves of each type were used. They were scanned and their images were digitalized using a desktop scanner connected to a computer. The leaves were dehydrated in an oven at $65^{\circ} \mathrm{C}$ until mass was constant. The sclerophylly index was calculated according to Rizzini (1976). The other 72 leaves of each type were used for microscopic analyses. An area of $25 \mathrm{~mm}^{2}$ in the midline portion of the leaves was selected and fixed in formaldehyde, acetic acid and $70 \%$ ethanol (FAA) at 9:0.5:0.5 (v:v:v) for $48 \mathrm{~h}$ (Johansen 1940) and stored in $70 \%$ ethanol (Berlyn \& Miksche 1976) until processing. The permanent slides of cross-sections were obtained after 36 samples of fertile leaves and 36 samples of sterile leaves were embedded in methacrylate (HistoResin, Leica), as described by Feder \& O'Brien (1968), and according to the manufacturer's instructions. The samples were embedded transversally. Samples were sectioned at a thickness of $7 \mu \mathrm{m}$ using a rotatory microtome (Leica RM 2125 RT) with disposable blades (Leica 818). The sections were stained with $0.05 \%$ toluidine blue (Sakai 1973) and mounted using synthetic resin $\left(\right.$ Entellan $\left.^{\circledR}\right)$. The semi-permanent slides of paradermal sections were obtained after dissociation (Franklin 1946) of other 36 leaves of each type, which were later stained with $0.05 \%$ toluidine blue (Sakai 1973), mounted on $50 \%$ glycerin and luted with clear nail polish (Purvis et al. 1964). Slides were mounted with epidermis samples of the two faces of the leaves to classify the leaves according to the occurrence of stomata.

The permanent and semi-permanent slides were digitalized using a photomicroscope (Olympus CX 41) coupled to a DC 3000 camera (Micrometrics $^{\mathrm{TM}}$ ) and software Micrometrics SE Premium ${ }^{\circledR}$ 2.9. The sections were described according to Van Cotthem (1970), Ogura (1972), White (1974), Sen \& Hennipman (1981) and Hernández et al. (2006).

After digitizing the macroscopy and microscopy images, thicknesses (leaf blade, epidermis, hypodermal tissue, midrib and sclerified layer), areas (leaf blade, vascular bundle and stoma), leaf width and length, and stomatal density (Fig. 2A, 2C) were obtained through

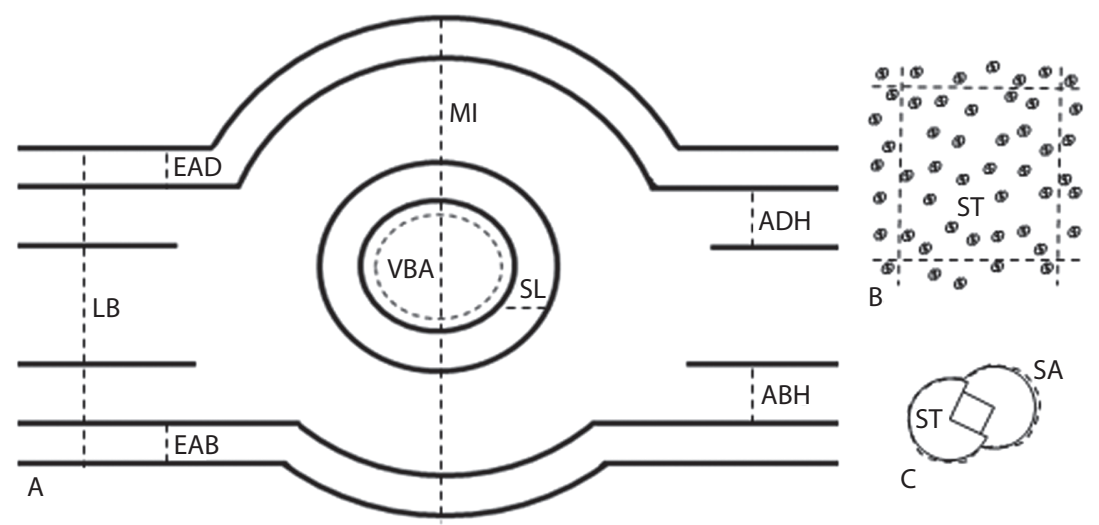

Fig. 2. Parameters measured on Microgramma squamulosa leaves. (A) Cross-section: epidermis-adaxial face (EAD); epidermis-abaxial face (EAB); adaxial hypodermis (ADH); abaxial hypodermis (ABH); leaf blade (LB); midrib (MI); sclerified layer (SL); vascular bundle area (VBA). (B) Paradermal section-representative quadrant to calculate stomatal density: stomata (ST) (quadrant area $=1 \mathrm{~mm}^{2}$ ). (C) Paradermal section-stoma area (SA). 
the Micrometrics SE Premium ${ }^{\circledR} 2.9$ software, using the method adapted from Godoi et al. (2010) and Santos et al. (2010). The thickness of the hypodermal tissue was calculated as the mean of the abaxial and adaxial hypodermal thicknesses of each leaf. Stomatal density was analyzed after the software provided a random definition $1 \mathrm{~mm}^{2}$ areas for each paradermal section, and one quadrant per section was examined for each leaf (Fig. 2B).

To compare quantitative parameters between fertile and sterile leaves, the SPSS 17.0 was used. The Shapiro-Wilk test was used to confirm normal data distribution. As the hypothesis of normal distribution was rejected, the Mann-Whitney test was used, and the level of significance was set at $5 \%$.

\section{RESULTS}

The fertile and sterile leaves presented no qualitative structural differences. The cross sections of the leaf types showed uniseriate epidermis in both faces. Stomata were at the same or a little higher level than the other epidermal cells (Fig. 3A, 3B). The interior faces
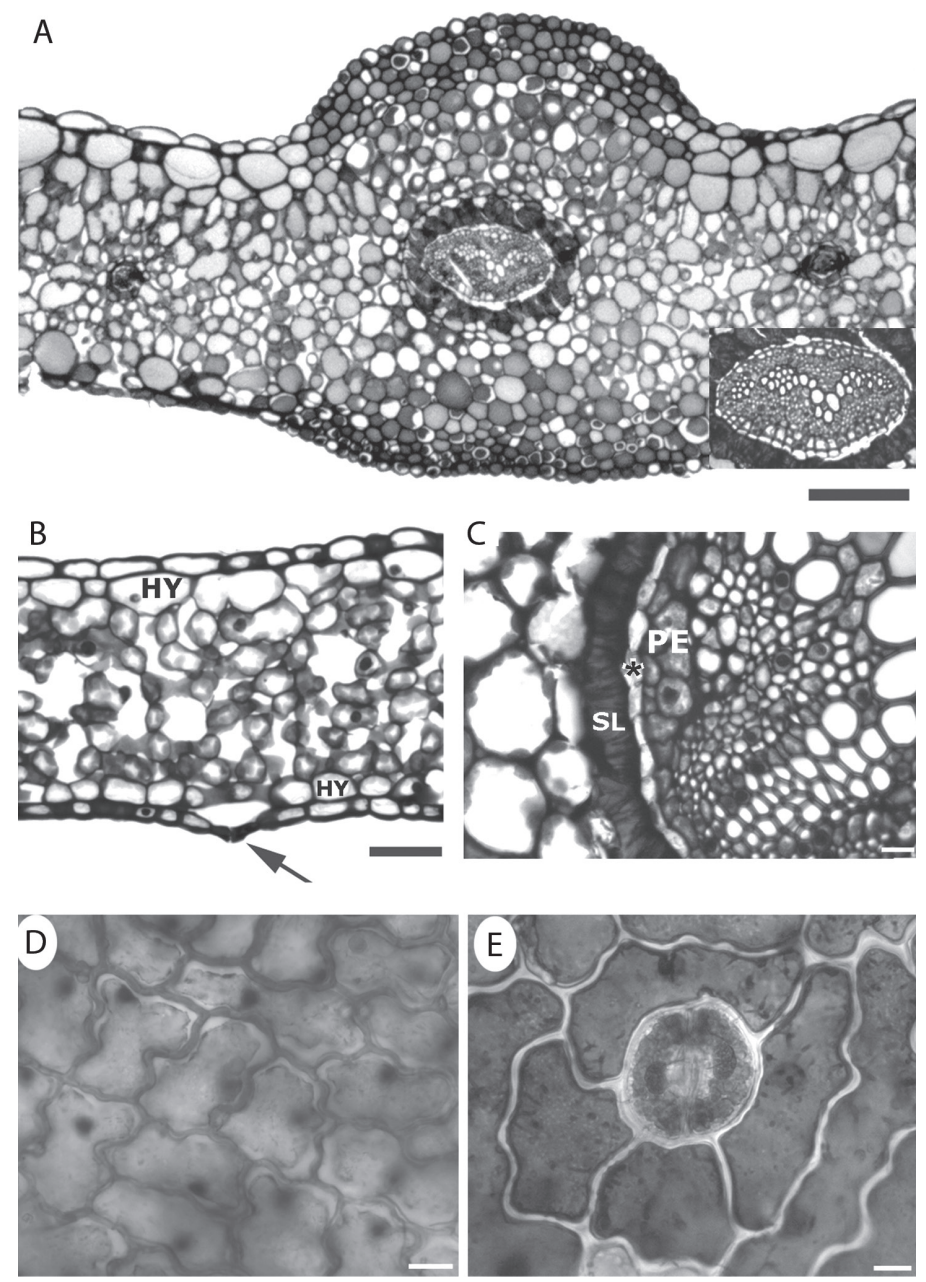

Fig. 3. Fertile and sterile leaf sections of Microgramma squamulosa. (A) Epidermis, midrib and mesophyll, bar: $100 \mu \mathrm{m}$ (insert-detailed view of V-shaped xylem, bar: $50 \mu \mathrm{m})$. (B) Epidermis, mesophyll pointing the hypodermis (HY) and stoma (arrow) in cross section, bar: $50 \mu \mathrm{m}$. (C) Midrib-detail of sclerified layer (SL), endodermis $(*)$ and pericycle (PE), bar: $10 \mu \mathrm{m}$. (D) Adaxial face, bar: $20 \mu \mathrm{m}$. (E) abaxial face: anomocytic stomatal complex, bar: $15 \mu \mathrm{m}$. 
of the epidermis were followed by 1-2 layers of hypodermal cells, with the abaxial hypodermis presenting smaller cells than those observed in the adaxial hypodermis. The central region showed a homogeneous chlorenchyma with intercellular spaces and small vascular bundles (Fig. 3A, 3B).

The midrib had an amphicribal vascular bundle with a V-shaped xylem (Fig. 3A). A sclerified layer, whose cells had a brownish content, was seen outside the endodermis surrounding all the vascular bundle (Fig. 3C).

The epidermal cells had sinuous walls both on the adaxial (Fig. 3D) and abaxial (Fig. 3E) faces. Front views showed that fertile and sterile leaves presented stomata only on the abaxial face, characterizing them as hypostomatous. The stomatal complexes were anomocytic, with two to five cells surrounding the guard cells (Fig. 3E).

The comparative statistical analysis of fertile and sterile leaves revealed that there were no significant differences between the thicknesses of the adaxial and abaxial epidermis faces, the hypodermal tissue, the sclerified layer, the leaf blade, the midrib; and between the areas of the vascular bundle and the stomata. Sterile leaves showed a significantly larger leaf blade area $\left(14.80 \mathrm{~cm}^{2}\right)$, higher sclerophylly index $\left(0.13 \mathrm{~g} / \mathrm{cm}^{2}\right)$ and higher stomatal density $\left(27.75 \mathrm{stomata} / \mathrm{mm}^{2}\right)$ than fertile leaves (Table 1).

\section{DISCUSSION}

Ferns show adaptations which permit their survival under extreme environmental conditions (Page 2002). In the present study, xeromorphic characteristics of $M$. squamulosa such as the occurrence of stomata on the abaxial face were evidenced. According to Dickison (2000), hypostomatous leaves lose less water than plants that have stomata on the adaxial face because this face of the epidermis is directly exposed to sunlight, which significantly increases the temperature and elevates the level of transpiration. Furthermore, the distribution of stomata is related with the thickness of the leaf, i.e. thinner leaves tend to be hypostomatous and present a lower intercellular resistance than thicker leaves (Parkhurst 1978).

The anomocytic stomatal complex of M. squamulosa was also found in various Polypodium species studied by Tejero-Díez et al. (2010), another genus of Polypodiaceae. However, this is not a pattern of this family, since Tejero-Díez et al. (2010) also registered other stomatal complexes and Sen \& De (1992) emphasized that the variability of types is common in ferns.

The chlorenchyma was the most abundant tissue of the mesophyll of M. squamulosa. De la Sota (1963) observed that M. megalophylla (Desv.) de la Sota leaves present a thin central chlorenchyma associated to a tissue which is formed by great and almost empty cells that assist in collecting diffuse light.

Epiphytes are exposed to higher light incidence and to a higher water deficit. Plants under these conditions tend to present high stomatal density (Larcher 2000). The greater number of stomata, the higher is the efficiency during gas exchange when the plant is under hydric stress (Mauseth 1988). Investigations with fern species demonstrated that the number of stomata is related with water availability (Hietz \& Briones 1997). Although under the same light conditions, the sterile leaves of M. squamulosa presented more stomata than the fertile leaves, what may contribute to a major xeromorphism.

This study demonstrated that the sterile leaves of M. squamulosa were wider, resulting into greater areas, although the fertile were longer. Previously, Sehnem (1970) and Jaime et al. (2007) reported different sizes of both leaf types, although no statistical comparisons were made by these authors. Fertile leaves measured 3 to $10 \mathrm{~cm}$ in length, and were up to $1.5 \mathrm{~cm}$ wide, whereas sterile leaves were about $15 \mathrm{~cm}$ long and $2 \mathrm{~cm}$ wide. In the present study, both foliar types exhibited dimensions close to those described by the authors, except for the length of the fertile leaves that was greater. According to Mehltreter (2008), the production of larger fertile leaves could be too costly, causing a 


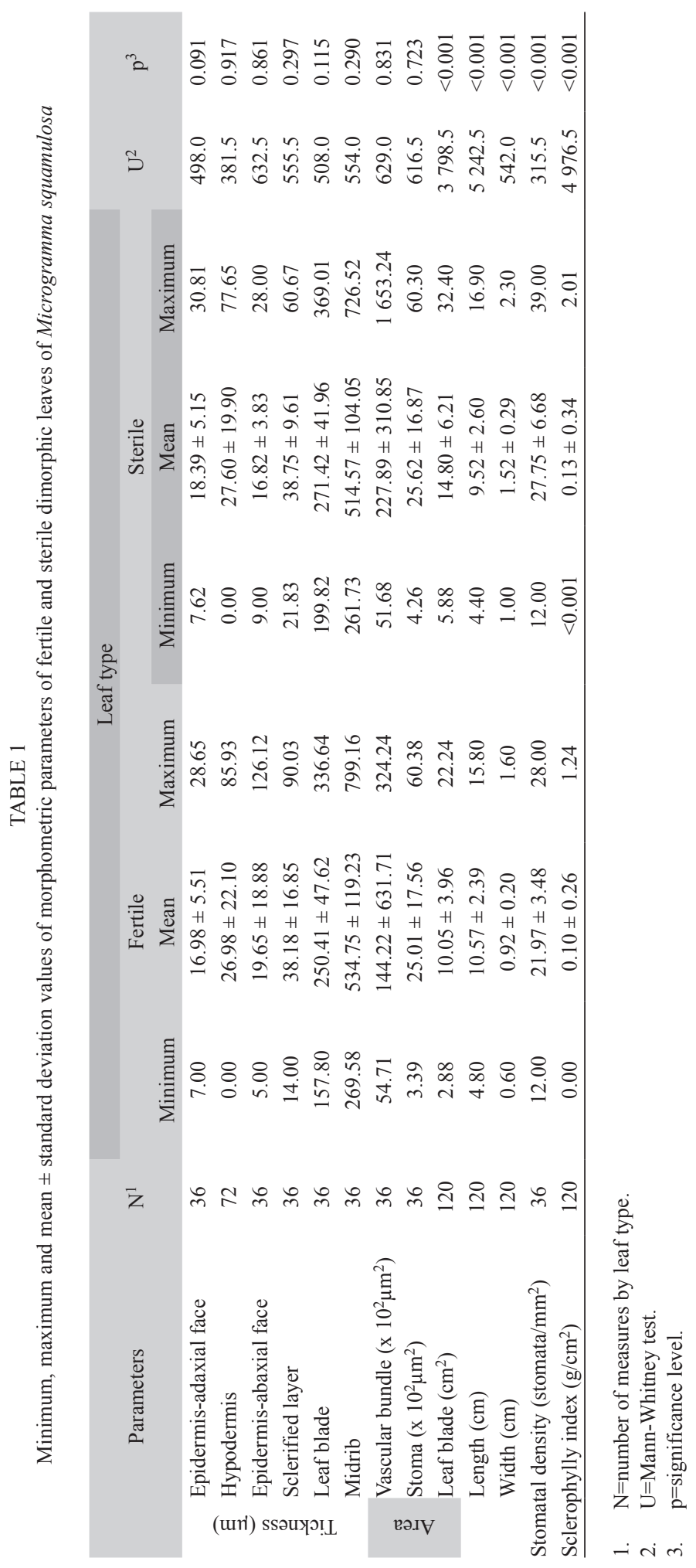


decreased rate of sporangial development in dimorphic species.

The V-shaped xylem observed in $M$. squamulosa was also registered by Ribeiro et al. (2007) for Anemia villosa Humb. \& Bonpl. ex Willd. (Anemiaceae). In species of the Polypodium plesiosorum group, TejeroDíez et al. (2010) described the xylem as C, $\mathrm{X}$ and T-shaped.

The sclerified layer of M. squamulosa surrounding the cells of the vascular bundle was also seen in the rhizome of this species by Suffredini et al. (2008). The species also has phenolic compounds (Jaime et al. 2007), which are responsible for the brownish color of the support tissues and parenchymal cells close to the vascular bundle (Ogura 1972), as found in this study.

The presence of hypodermal tissue in $M$. squamulosa leaves is a typical characteristic of xeromorphic leaves; it is responsible for water storage and also participates in plant support (Kraus 1949, Esau 1965). Tejero-Díez et al. (2010) observed the presence of a hypodermis in the leaves of Polypodium species (Polypodiaceae). In epiphytic angiosperms, NogueraSavelli \& Jáuregui (2011) also reported the occurrence of hypodermis in only four of 11 analyzed species of Orchidaceae. The authors observed that the hypodermis was disposed in different ways, indicating variability in the arrangement in different epiphytic species.

The hypodermis that is considered the most common structure responsible for temperature maintenance and water storage in epiphytes (Madison 1977) was also registered for M. squamulosa. The xeromorphic characteristics of epiphytic plants are an adaptation to the environment where water is supplied in pulses (Benzing 1990). In addition to the hypodermis, the Microgramma species present specialized mechanisms for light collecting and have starch reserves that ensure the survival of the plant in an epiphytic environment (de la Sota 1963, Dubuisson et al. 2009). Hietz \& Briones (1997) studied the relation between water availability and the distribution of epiphytic ferns and verified that even species that developed into humid forests show adaptations to xeromorphism.

Fertile and sterile leaves of M. squamulo$s a$ are classified as sclerophyllous by Rizzini (1976) because they have a sclerophylly index below $0.6 \mathrm{~g} / \mathrm{cm}^{2}$. Despite the equal classification, the sterile leaves showed sclerophylly indexes statistically higher than the fertile leaves. Sclerophyll leaves are adapted to environments where water is supplied in pulses because they can reduce their excessive water loss (Sobrado $\&$ Medina 1980) and are also more resistant to herbivory (Edwards et al. 2000).

Leaf dimorphism is frequent in epiphytes, although little is known about the variables which control or induce appearance of fertile leaves. These variables include climatic sazonality or are related to other exogenous factors, to the age of the plants and to their distribution on different zones of the phorophyte, or even, fertile leaves can appear apparently, spontaneously (de la Sota 1971). In the present study, there was found a predominance of sterile compared to fertile leaves, as usually observed for M. squamulosa. These sterile leaves may invest more in biochemical defenses against herbivores and, therefore, have a higher specific leaf mass (Mehltreter 2008). The higher leaf mass resulted in the higher sclerophylly index, which combined with the higher stomatal density can diminish water loss.

\section{ACKNOWLEDGMENTS}

The authors are thankful to the Universidade Feevale for support and to Coordenação de Aperfeiçoamento de Pessoal de Nível Superior (CAPES) for the master scholarship to the first author.

\section{RESUMEN}

El helecho epífito Microgramma squamulosa se encuentra en el Neotrópico y tiene hojas estériles y fértiles dimorfas. El objetivo de este estudio fue describir y comparar cuantitativa y cualitativamente la organización estructural de las hojas de la M. squamulosa, investigando las características morfológicas y anatómicas, y señalando los factores que contribuyen a la adaptación al ambiente 
epífito. Los análisis macroscópicos y microscópicos se realizaron a partir de 192 muestras de hojas de cada tipo. Láminas permanentes y semi-permanentes fueron preparadas y las secciones fueron observadas en el microscopio de luz. Hojas fértiles y estériles no mostraron diferencias estructurales cualitativas, son hipostomáticas, presentan epidermis uniseriada, haz vascular anficrival e hipodermis. La presencia de hipodermis y aparatos estomáticos en la superficie abaxial de la epidermis son típicas de hojas xeromórficas. Hojas estériles presentaran áreas significativamente mayores, tasa más alta de esclerofilia y mayor densidad de estomas que hojas fértiles. La mayor tasa de esclerofilia y mayor densidad de estomas son características que hacen las hojas estériles más xeromórficas, aumentando su eficiencia para hacer frente a la disponibilidad de agua limitada en el ambiente epífito, en comparación con las hojas fértiles.

Palabras clave: hoja fértil, hoja estéril, helecho, epífito, morfometria, xeromorfismo.

\section{REFERENCES}

Benzing, D.H. 1990. Vascular epiphytes. Cambridge University, New York, USA.

Berlyn, G.P. \& J.P. Miksche. 1976. Botanical microtechnique and cytochemistry. Iowa University, Iowa City, USA.

de la Sota, E.R. 1963. 'Microgramma megalophylla' (Polypodiaceaes.str.), uma interessante espécie de Amazonas. Bol. Soc. Arg. Bot. 10: 158-165.

de la Sota, E.R. 1971. El epifitismo y las pteridofitas en Costa Rica (América Central). N. Hedwigia 21: 401-465.

Dickison, W.C. 2000. Ecological anatomy, p. 295-337. In W.C. Dickison (ed.). Integrative plant anatomy. Harcourt Academic, San Diego, USA.

Dubuisson, J.Y., H. Schneider \& S. Hennequin. 2009. Epiphytism in ferns: diversity and history. C. R. Biol. 332: 120-128.

Edwards, C., J. Read \& G.D. Sanson. 2000. Characterizing sclerophylly: some mechanical properties of leaves from heathland and forest at Wilson's Promontory, Australia. Oecologia 123: 158-167.

Esau, K. 1965. Plant anatomy. John Wiley \& Sons, New York, USA.

Feder, N. \& T.P. O’Brien. 1968. Plant microthecnique some principles and new methods. Amer. J. Bot. 55: 123-142.

Franklin, G.L. 1946. A rapid method of softering wood for microtome sectioning. Trop. Woods 88: 35-36.

Godoi, A.F.L., R.H.M. Godoi, R. Azevedo \& L.T. Maranho. 2010. Poluição e a densidade de vegetação:
BTEX em algumas áreas públicas de Curitiba - PR, Brasil. Quím. Nova 33: 827-833.

Gonçalves, C.N. \& J.L. Waechter. 2003. Aspectos florísticos e ecológicos de epífitos vasculares sobre figueiras isoladas no norte da planície costeira do Rio Grande do Sul. Acta Bot. Bras. 17: 89-100.

Graçano, D., A.A. Azevedo \& J. Prado. 2001. Anatomia foliar de Pteridaceae do Parque Estadual do Rio Doce (PERD)-MG. Rev. bras. Bot. 24: 337-347.

Hernández, M., P. Albornoz, F. Rodríguez \& S. Serrano. 2008. Anatomía de rizoma, raíz y micorrizas arbusculares en Cheilanthes pruinata Kaulf. y C. myriophylla Desv. (Pteridaceae) en el Noroeste Argentino. Lilloa 45: 73-82.

Hernández, V., T. Terraza \& G. Angeles. 2006. Anatomía de seis especies de helechos del género Dryopteris (Dryopteridaceae) de México. Rev. Biol. Trop. 54: 1157-1169.

Hietz, P. \& O. Briones. 1997. Correlation between water relations and within-canopy distribution of epiphytic ferns in a Mexican cloud forest. Oecologia 114: 305-316.

Hirsch, A.M. \& D.R. Kaplan. 1974. Organography, branching, and the problem of leaf versus bud differentiation in the vining epiphytic fern genus Microgramma. Amer. J. Bot. 61: 217-229.

Jaime, G.S., G. Barboza \& M.A. Vattuone. 2007. Sobre los caracteres foliares diagnósticos de Microgramma squamulosa (Kaulf.) Sota (Polypodiaceae). Blacpma 6: 195-196

Johansen, D.A. 1940. Plant microtechnique. McGraw-Hill, New York, USA.

Jones, D.L. 1987. Encyclopaedia of ferns: an introduction to ferns, their structure, biology, economic importance, cultivation, and propagation. Lothian, Melbourne, Australia.

Kersten, R.A. \& S.M. Silva. 2002. Florística e estrutura do componente epifítico vascular em floresta ombrófila mista aluvial do rio Barigüi, Paraná, Brasil. Rev. bras. Bot. 25: 259-267.

Kraus, B.H. 1949. Anatomy of vegetative organs of the pineapple Ananas comosus (L.) Merr. II. The leaf. Bot. Gazette 110: 303-404.

Kress, W.J. 1986. The systematic distribution of vascular epiphytes: an update. Selbyana 9: 2-22.

Larcher, W. 2000. Ecofisiologia vegetal. Rima Artes e Textos, São Carlos, Brazil.

Madison, M. 1977. Vascular epiphytes: their systematic occurrence and salient features. Selbyana 2: 1-13.

Mauseth, J.D. 1988. Plant anatomy. Benjamin Cummings, Menlo Park, USA.

Mehltreter, K. 2008. Phenology and habitat specificity of tropical ferns, p. 201-221. In R.A. Ranker \& C.H. 
Haufer (eds.). Biology and evolution of ferns and lycophytes. Cambridge University, New York, USA.

Moreno, J.A. 1961. Clima do Rio Grande do Sul. Governo Porto Alegre, Porto Alegre, Brazil.

Noguera-Savelli, E. \& D. Jáuregui. 2011. Anatomía foliar comparada y relaciones filogenéticas de 11 especies de Laeliinae con énfasis en Brassavola (Orchidaceae). Rev. Biol. Trop. 59: 1047-1059.

Ogura, Y. 1972. Comparative Anatomy of vegetative organs of the Pteridophytes. Gebrüder Bornträger, Berlin, Germany.

Page, C.N. 2002. Ecological strategies in fern evolution: a neopteridological overview. Rev. Palaeobot. Palynol. 119: 1-33.

Parkhurst, D.F. 1978. Adaptative significance of stomatal occurrence on one or both surfaces of leaves. J. Ecol. 66: 367-383.

Proença, S.L \& M.G. Sajo. 2007. Anatomia foliar de bromélias ocorrentes em áreas de cerrado do Estado de São Paulo, Brasil. Acta Bot. Bras. 21: 657-673.

Purvis, M.J., D.C. Collier \& D. Walls. 1964. Laboratory techniques in botany. Butterworths, London, United Kingdom.

Ribeiro, M.L.R.C., M.G. Santos \& M.G. Moraes. 2007. Leaf anatomy of two Anemia Sw. species (Schizaeaceae-Pteridophyte) from a rocky outcrop in Niterói, Rio de Janeiro, Brazil. Rev. bras. Bot. 30: 695-702.

Rizzini, C.T. 1976. Tratado de fitogeografia do Brasil. Edusp/Hucitec, São Paulo, Brazil.

Sakai, W.S. 1973. Simple method for differential staining of parafin embedded plant material using toluidine blue. Stain Technol. 48: 247-249.

Salino, A., T.E. Almeida, A.R. Smith, A.N. Gómez, H.P. Kreier \& H. Schneider. 2008. A new species of Microgramma (Polypodiaceae) from Brazil and recircumscription of the genus based on phylogenetic evidence. Syst. Bot. 33: 630-635.

Santos, M., P.C.P. Fermino Junior, M.G. Vailati \& M.T.S. Paulilo. 2010. Aspectos estruturais de folhas de indivíduos de Guapira opposita (Vell) Reitz (Nyctaginaceae) correntes em Restinga e na Floresta Ombrófila Densa. Insula 39: 59-78.

Sen, U. \& E. Hennipman. 1981. Structure and ontogeny of stomata in Polypodiaceae. Blumea 27: 175-201.
Sen, U. \& B. De. 1992. Structure and ontogeny of stomata in ferns. Blumea 37: 239-261.

Sehnem, A.S.J. 1970. Polipodiáceas, p. 173. In R. Reitz (ed.). Flora Ilustrada Catarinense, parte I, fasc. POLI. Herbário Barbosa Rodrigues, Itajaí, Brazil.

Smith, A.R., K.M. Pryer, E. Schuettpelz, P. Korall, H. Schneider \& P.G. Wolf. 2008. Fern classification, p. 417467. In T.A. Ranker \& C.H. Haufler (eds.). Biology and evolution of ferns and lycophytes. Cambridge University, New York, USA.

Sobrado, M.A. \& E. Medina. 1980. General morphology, anatomical structure, and nutrient content of sclerophyllous leaves of the "bana" vegetation of Amazonas. Oecologia 45: 341-345.

Suffredini, I.B., E.M. Bacchi \& J.E. Kraus. 2008. Estudo farmacognóstico do caule e raízes de Microgramma squamulosa (Kaulf.) Sota (Polypodiaceae). Rev. bras. farmacogn. 18: 279-286.

Suffredini, I.B., E.M. Bacchi \& J.A.A. Sertiè. 1999. Antiulcer action of Microgramma squamulosa (Kaulf.) Sota. J. Ethnopharmacol. 65: 217-23.

Teixeira, M.B., A.B. Coura Neto, U. Pastore \& A.L.R. Rangel Filho. 1986. Vegetação, p. 541-632. In Levantamento dos Recursos Naturais. IBGE, Rio de Janeiro, Brazil.

Tejero-Díez, J.D., S. Aguilar-Rodríguez, T. Terrazas \& L. Pacheco. 2010. Arquitectura y anatomía foliar del complejo Polypodium plesiosorum sensu Moran (Polypodiaceae). Rev. Biol. Trop. 58: 955-976.

Tryon, R.M. \& R.G. Stolze. 1993. Pteridophyta of Peru. Part V. 18. Aspleniaceae 21. Polypodiaceae. Fieldiana Bot. 32: 1-190.

Tryon, R.M. \& A.F. Tryon. 1982. Ferns and allies plants with special references to tropical America. SpringerVerlag, New York, USA.

Van Cotthem, W.R.J. 1970. A classification of stomatal types. Bot. J. Linn. Soc. 63: 235-246.

White, R.A. 1974. Comparative anatomical studies of the ferns. Ann. Missouri Bot. Gard. 61: 379-387.

Zanenga-Godoy, R. \& C.G. Costa. 2003. Anatomia foliar de quatro espécies do gênero Cattleya Lindl. (Orchidaceae) do planalto central brasileiro. Acta Bot. Bras. 17: 101-118. 
